\title{
Aesthetics for green roofs and green walls
}

\author{
Richard K. Sutton ${ }^{1}$ \\ ${ }^{1}$ Professor, University of Nebraska-Lincoln, Lincoln, NE, rsutton1@unl.edu
}

Sutton, R., 2014. Aesthetics for green roofs and green walls. Journal of Living Architecture. 1(2): 1-20.

http://greenroofs.org/resources/JOLA2014Volume1(Issue2)Sutton 


\begin{abstract}
Do green roofs and green walls have aesthetic benefits? Most green roof proponents would say so. But what are they and how do they relate to green roof design in terms of species selection, planting arrangement, viewable context, access, maintenance and other factors? Aesthetics according to the Green Roof Design 101 Manual $2^{\text {nd }}$ Ed (GRHC 2006) provides "pleasure- and psycho-physiologically-oriented benefits" but, this narrow understanding suggests that the aesthetic potential of green roofs is limited to what one might experience looking upon any garden. We suggest other ways that need exploring to make aesthetics more relevant and understandable to the practice of wall and roof greening.
\end{abstract}

We suggest other ways that need exploring to make aesthetics more relevant and understandable to the practice of wall and roof greening.

Keywords: Aesthetics, Enjoyable beauty, Admirable beauty, Ecological beauty, Biodiversity

\title{
Introduction
}

Most green roof and green wall advocates tout improved urban aesthetics as a benefit, yet other than a passing reference to stimulating an urban dweller, reducing stays in hospitals, or lowering the amounts of pain medication for patients, few other reasons have been offered. Ulrich's (1984) widely referenced article indicated that patients in a monotonous hospital environment had shorter stays and reduced pain medicine among other positive affective responses with window views of nature. The implication has been that green roof and wall views may have the same impact. Yet applying such affective or psycho-physiological benefits to a green roof (e.g., Lee and Koshimitz 2006) really is no different than applying them to a landscape garden. Such tenuous aesthetic support does not represent the totality of aesthetic benefits accruing to green roofs and green walls. Nor does it delve more deeply into understanding of aesthetics generally or environmental aesthetics in particular. We expand below on several ideas to help demonstrate that an aesthetic experience, (i.e., an experience of beauty) can be deeper, more encompassing, and much more sustaining than simply a hedonistic response to pleasure.

According to Webster's $7^{\text {th }}$ Collegiate Dictionary, aesthetics has these meanings:

1) a branch of philosophy that deals with the nature of the beautiful and judgments concerning beauty

2) description and explanation of artistic phenomena and aesthetic experience by means of social sciences such as psychology, sociology, ethnology, or history. 
So philosophers and social scientists, not just critics and designers, help us judge and understand beauty. Beauty covers a suite of human experiences, affects, emotions, and thoughts and as we can gauge from the definitions; applied beauty fully integrates a process of description, interpretation, and evaluation. Make no mistake: when one talks about aesthetics and beauty, or ugliness, the discussion broadly involves value judgments.

At least two aspects occur during that evaluation. First, there must be something describable that arouses a judgment; second, an evaluator offers judgment. Aesthetics allows us to judge our feelings and value our responses on a scale from value to disvalue and judgment may not always be positive. Examining the disvalues below can help illustrate a broad range of concerns and interactions found in real situations. For example, below are some common disvalues (from Berleant 1997):

- "Banal - acquiesces to conventional style, subject matter, or sentiment

- Dull - no invention, poor technique, shallow imagination

- Unfulfilled - something's missing; a good idea poorly executed

- Trite - ignores new possibilities

- Inappropriate - not suitable to its context

- Desensitizing - ignores a place's sensory richness or our perceptual completeness

- Deceptive - hiding faults; lacking truthfulness

- Destructive - degrades context or demeans user"

Notice how some, but not all, of the listed disvalues involve only the feature being judged. Some disvalues call to question the skill and intention of the designer, or focus not just on the feature or creation, but its context. Others begin to describe harmful impacts on the evaluator.

\section{Three Categories of Beauty}

Describing and detailing beauty has occupied humans since at least the Ancient Greeks. Alder (1981) in his book, Six Great Ideas, proposes that beauty as studied by philosophers and our response to it can be reduced and summarized into the simple categories of enjoyable beauty and admirable beauty. Given the last several hundred years of philosophical study and debate, those two concepts work well to understand and interpret the beauty arising from human creations. But a problem occurs when nature specifically or the non-human environment in general, becomes the focus of aesthetic inquiry because, it is beyond human control or understanding. 
There is not enough room here to fully trace how interest rises and falls in aesthetics as applied to the environment. If the reader wishes more depth, Carlson (2012) has completed such review. In brief, Carlson's explication of environmental aesthetics goes beyond what Adler called enjoyable beauty and admirable beauty. Carlson describes and discusses the recent interest in environmental beauty as paralleling concern regarding the deterioration of our environment starting in the last part of the $20^{\text {th }}$ Century. Aestheticians (e.g. Hepburn 1966) working on the characteristics of the environment or nature relationships showed interest in our everyday environments and our interaction and response to natural elements and ecological processes. According to Carlson, cognitive views of environmental aesthetics use knowledge of nature while non-cognitive views rely on some other aspect such as nature's engagement of humans (Berleant 1997). Most recently, Carlson notes that some scholars of environmental aesthetics (e.g. Nassauer 1997) and ecological-based beauty are attempting to include multiple viewpoints.

Below we describe Adler's simple, but useful and accurate explanations of enjoyable beauty and admirable beauty, because those concepts fit and are widely espoused by many who envision the aesthetics of green roofs and walls. We then bring forward a wider and more useful concept of ecological beauty.

\section{ENJOYABLE BEAUTY}

St. Thomas Aquinas (1274) stated adroitly that beauty is, "that which being perceived, pleases." Such an idea of beauty, while it may be true, is, unfortunately, strongly subjective. It is one's opinion and no one else can confirm or deny that personal response. Its basis cannot be accessed; so therefore, it is not really open to dialog or persuasion. Much of the subjectivity of enjoyable beauty (Adler 1981) may be the result of cultural learning not shared by others. "Beauty is in the eye of the beholder" as a shallow and self-contained approach, tends to separate one from what catalyzed the aesthetic experience in the first place. Finally, its focus on immediate gratification also fails to deal with a wider older, and more complex context for the experience.

\section{ADMIRABLE BEAUTY}

Turning to what brought on the experience provides no more complete an explanation to an aesthetic experience either, since it focuses solely upon the stimulus' physical and admirable properties. This object-oriented approach, favored by art critics and many designers, may also be culturally learned and should acknowledge the intention of the artist. According to Kant (1792), contemplation or interpretation of an aesthetic experience must be a disinterested act. And just as enjoyable beauty requires separation of a subject and object, so does admirable beauty (Adler 1981). Often based solely on formal, visual elements such as 
color, texture, and form, and the design principles of variety, unity and proportion, this approach can become superficial and focus narrowly on pleasure derived from shallow surfaces. This pleasure or affect often ignores the surrounding context in favor of a designed object.

Explaining an aesthetic experience based upon admirable beauty brings several problems. First, not all critics agree that some object may be worthy of admiration or use widely different criteria to judge it. Cold, calculated criticism fails to account for human emotions and may be often biased in favor of only the sense of sight. Trapped in a static field, objects often belie and deny their changing context.

These arguments all seem fairly obvious when dealing with a solely human-created phenomena like a sculpture, painting or even a building, but things become more complicated when natural phenomena (like plant growth on a green roof or wall) come into play. When an ecological system, however much it was designed and initiated by a human, takes on a life of its own, we need a different more encompassing approach to beauty.

\section{ECOLOGICAL BEAUTY}

Ecological beauty arises from the subject (individual user), object (landscape) and their higher order connection (Individual-landscape-context) (Gobster 1999). In this approach, subject, object and context become unified. Focusing on interaction frames ecological beauty hierarchically much like nature herself. Beauty and its perception emerge from these underlying properties and interactions. An ecological approach to beauty thus extends beyond mere surface properties and embraces unseen forms and processes, deeply and holistically engaging our personal experience. This deep experience simultaneously draws upon our knowledge and teaches us about our general environment. Over time, experience bonds us to a specific place. Unlike enjoyable or admirable beauty, ecological beauty makes no attempt to control the subject with esoteric cultural knowledge or the object with precise description. Those who desire perfection in aesthetic experience will be disappointed with ecological beauty because humans will never have enough knowledge to perfectly describe or specify all natural features, contexts, and processes.

Aldo Leopold (1949) in his classic book, A Sand County Almanac, developed the wellknown valuation system called the "Land Ethic" and in the same book also sketched out another valuation system he called the "Conservation Esthetic"(sic). Callicot (1983) recounts the differences and similarities in Leopold's valuation systems. The Conservation Esthetic

Table 1. Three Categories of Beauty

$\begin{array}{lll}\text { Enjoyable Admirable } & \text { Ecological }\end{array}$


Subjective

Cultural model (learned)

All about one's experience

Sensory-based pleasure

Separation of viewer from object Opinion not open to discussion Internalized

Descriptive

Criticism

Shallow and self-contained Does not deal with context
Objective

Art model

Product of intentional creative act

Requires disinterested interpretation

Separation of viewer from context Judged in isolation of its context Superficial, shallow-surfaced

Normative

Primarily visual
Object/Subject interact

Biological/Cognitive model

Interactive; hierarchical

Pleasure requires active interpretation/ knowledge

Object/Subject/Context unified Evidence-based; emergent properties Based on formal characteristics Deeply engages one's experience

Multi-modal, uses all senses and movement

Teaches and bonds us with place

\section{Criticism}

Critics disagree, or use the same criteria How to access and apply human emotion?

Never will have enough knowledge Can't control context or viewer

Too often only visually-based

Static; denies change

recognizes the more common, directly visible and less scenic (i.e., non-superficial); it emphasizes benefits such as psychic and spiritual rewards. Unlike the Land Ethic, the Conservation Esthetic is non-consumptive and applies to private not just public places; it does not focus on obligations and responsibilities but offers spiritual rewards. The major connection between the two, interactive relationships, derives from ecology, albeit for the Conservation Esthetic it is more conceptual; it includes ideas of diversity, complexity, species rarity, nativity, their interactions and so on. Another key feature of the Conservation Esthetic encourages individuals over time to cultivate sensibilities and acquire knowledge about specific environments. In short, it evokes learning and ecological awareness that may take a lifetime to acquire.

Leopold's Conservation Esthetic embraces many of the aspects described earlier for ecological beauty such as interaction between subject and object with the subject capturing information that is beyond a "pretty" surface. As well, it allows a deep and knowledgeable experience to bond us with place over time. As alluded to earlier, ecological science's raison d'être seeks to unlock and explain how the ecological world works. However with regards to an ecological aesthetic, ecological science becomes propelled by lack of knowledge dampened neither by control of viewer nor by context. The essence of ecological beauty means that we will always be engaged and learning about it. 


\section{Ecological Aesthetic Guidelines Applied to Green Roofs and Walls}

\section{MAKE GREEN ROOFS AND WALLS CONSPICUOUS}

Over twenty years ago, landscape architect, Robert Thayer (1989) examined the nascent sustainable landscape. To him, it "symbolize[d] resource preservation through visual, spatial and sensory means to produce a positive affective response." Sustainable landscape features like green roofs and green walls also exemplify Thayer's idea that, "visibility and imageability of the sustainable landscape is critical to its experiential impact and the rate at which it will be adopted and emulated in common use" (p. 108). This means that for an ecological aesthetic to become understood and appreciated by the public, it must be seen and experienced (Figure 1). Accordingly, "conspicuous experiential quality" (Figures 2 and 3) will help speed the diffusion of change in aesthetic expectations (Thayer 1989).

\section{ALLOW HUMAN PARTICIPATION TO AID ECOLOGICAL KNOWING}

We must be able to interact with a design's natural elements and draw out information that conveys content as well as form (Figure 4). Arnold Berleant (1997) has offered new insight to this participatory aesthetics that he calls "aesthetics of engagement." It jibes with Gregory Bateson's (1979), statement about aesthetics as "be[ing] responsive to the pattern which connects." The design process allows for input from the client and potentially the user. An ecological aesthetic would capture such activity as a chance to educate and thus participate more fully in the design intent and implementation. 
Figure 1. While some green roofs like the Barney's New York retail store in Chicago may have limited access, viewers in nearby buildings still can experience its planted surface from a distance.

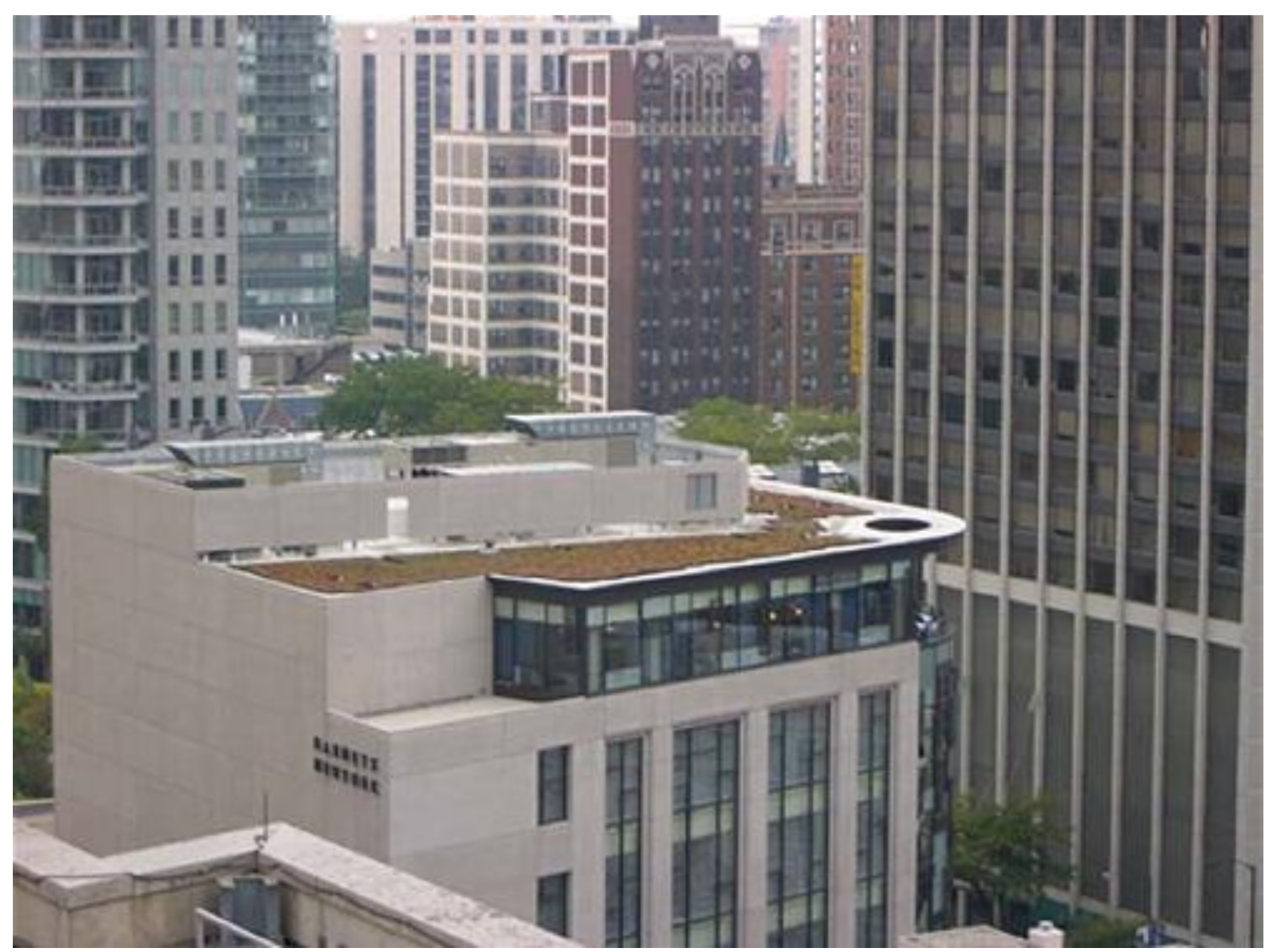


Figure 2. Thoughtful space design within the Vancouver Convention Centre captures green roof views and integrates user experience of outdoors and indoors. (Photo courtesy Vancouver Convention Centre.)

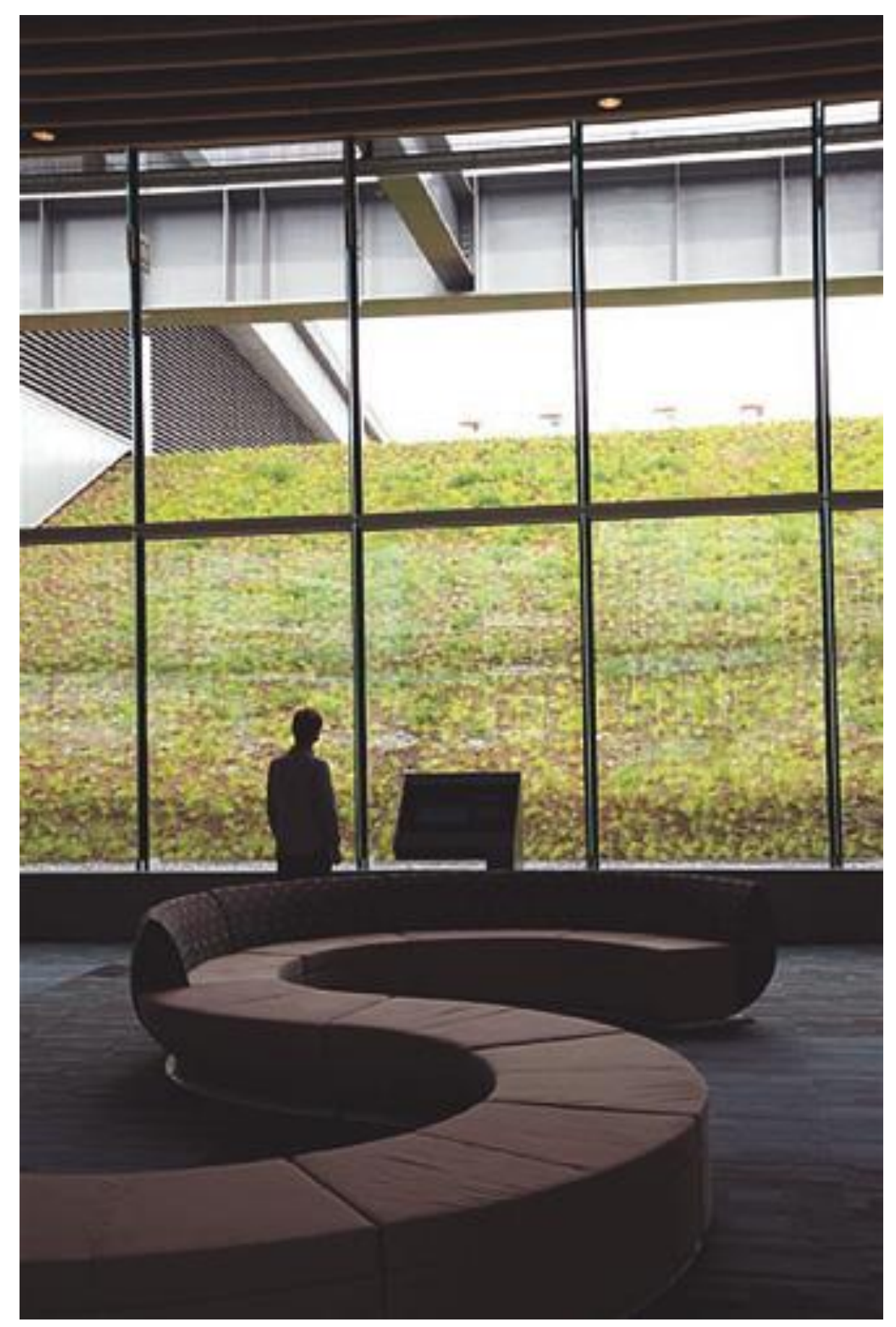


Figure 3. On axis with a main exit from the baggage collection area of the Vancouver International Airport, this green wall's bold, living textures intrigue users and its vertical plane confronts our experience of what a wall should be.

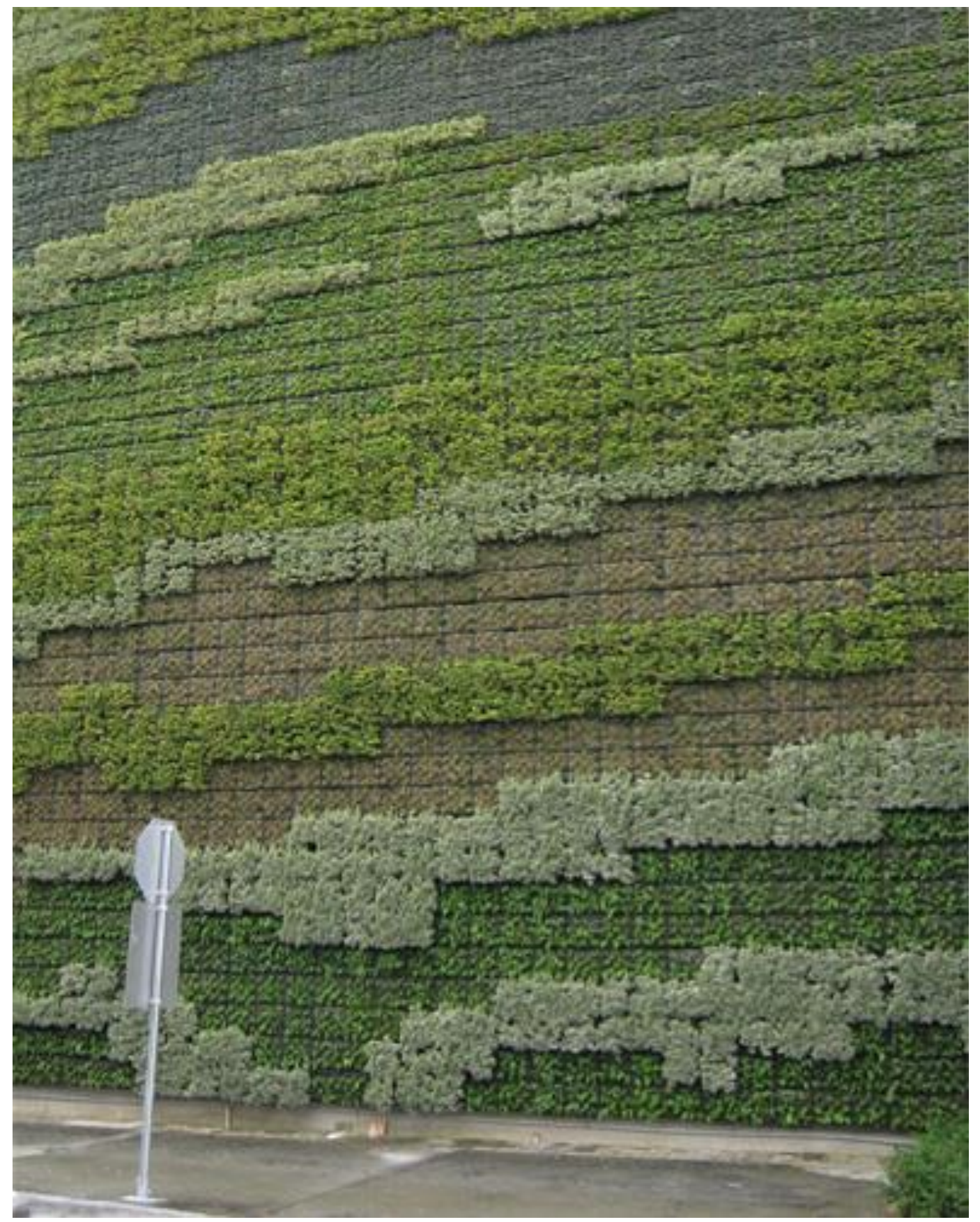


Figure 4. Native grasses and forbs on the Pioneers Park Nature Center green roof in Lincoln, Nebraska, reflect its visual context and support the center's mission of teaching the public about the local prairie ecosystem.

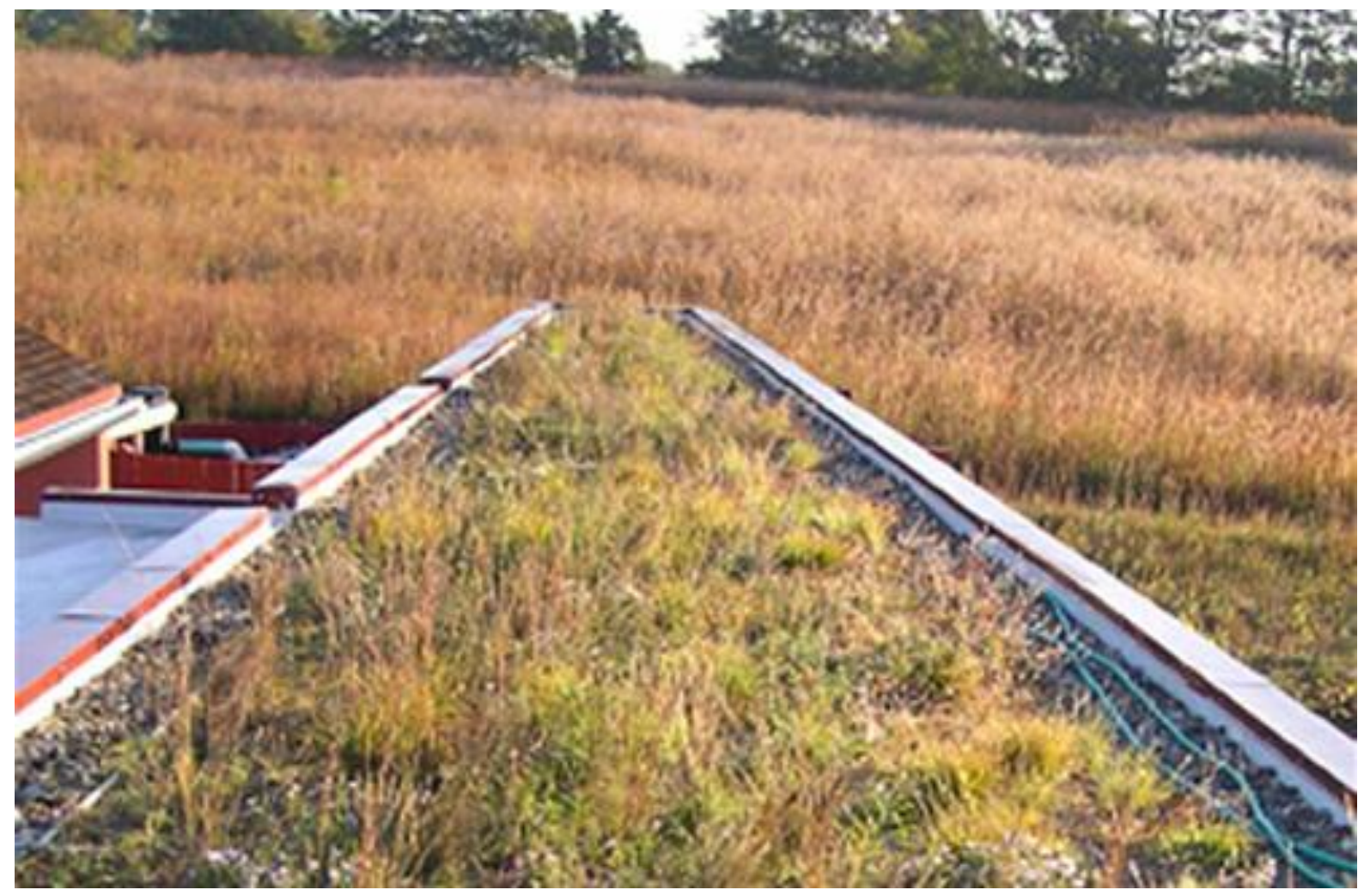

The result of response and participation, Thayer (1989) claims is, "People who are able to comprehend how and why a sustainable landscape functions will respond differently to that landscape than those who are uninformed... environmental knowing heightens landscape experience." This cumulative, educated effect comes from ". . . creating new associations between place and perception and displacing the old normative meanings of landscape context" (Figure 5). Complexity and diversity in content take time, training, and experience to discern. In using ecological beauty, we add the ecologist's knowledge with the artist's intent, thus raising our level of participation and interaction with the environment and ultimately improving our sense of connectedness. 
Figure 5. Honey harvested from hives supported by the flowering plants on Chicago's City Hall green roof lets one vicariously experience of the roof.

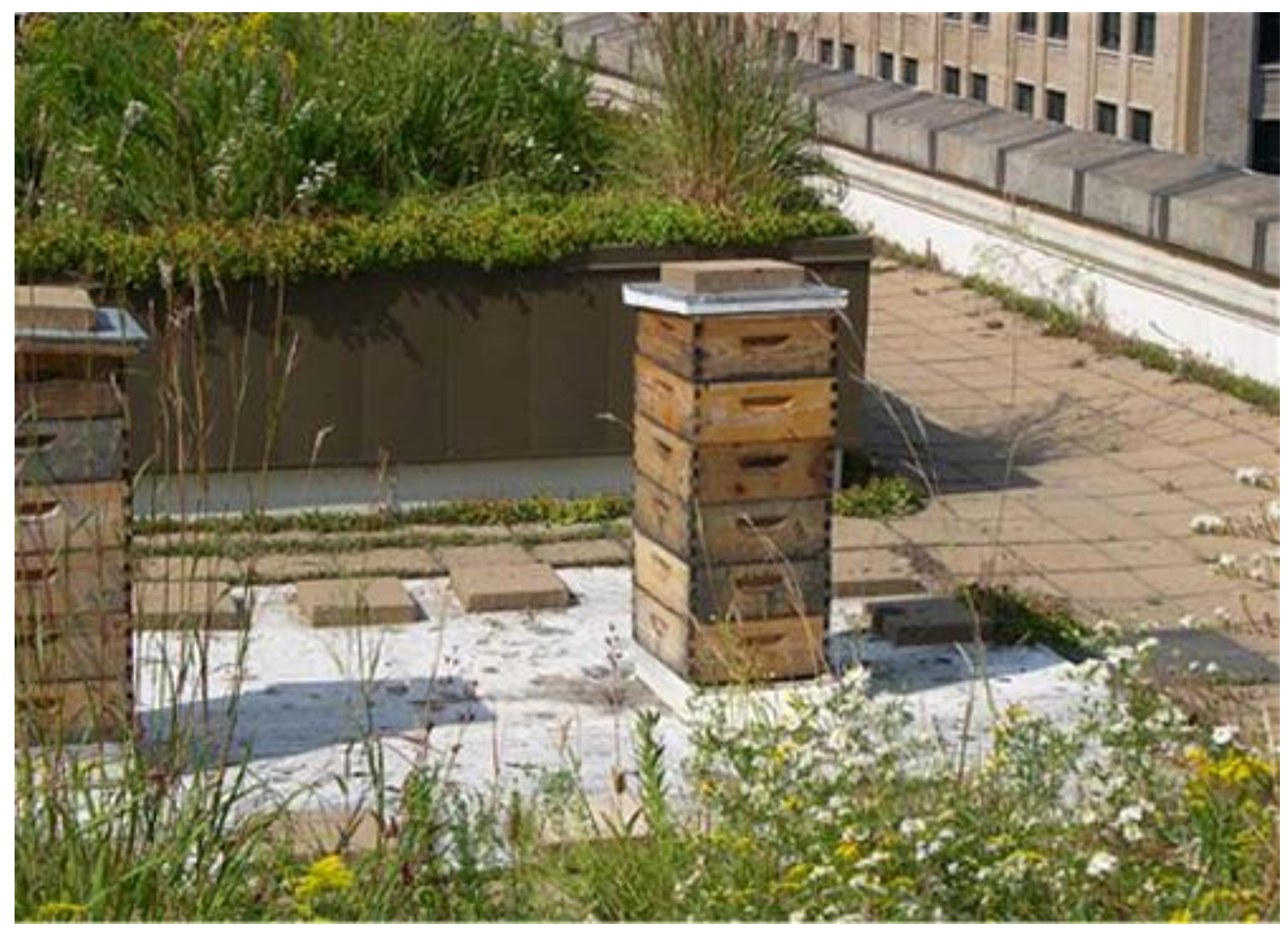

\section{CARE COMMUNICATES AND CONNECTS KNOWLEDGE, INTENT, AND COMMITMENT}

Peter Harries-Jones (2005) notes Gregory Bateson's ecological aesthetic examined "epistemological propositions that arose from and were expressive of forms of nature...patterns of recurrence; the perceptual abilities of all organisms engendered through their capacity for anticipatory response; a way in which the evident interconnectedness of nature is not simply a phenomena of physical interaction but is mediated through communication (p.65)." (Figure 6) Nassauer (1997) says that seeing and understanding connectedness is critical for humans; making connections makes us human. For example, to Nassauer, common landscapes communicate the owner's knowledge and may apply an aesthetic of care seen as intention and involvement. Naturalized landscapes "without a clear human intention seem unoccupied and invite human presence whatever its intention." 
Figure 6. Guided tours and interpretative signage on the Eco-Phillips extensive green roof in Minneapolis, Minnesota help communicate knowledge about the resident plants and the concept of sustainability intended by its low maintenance design.

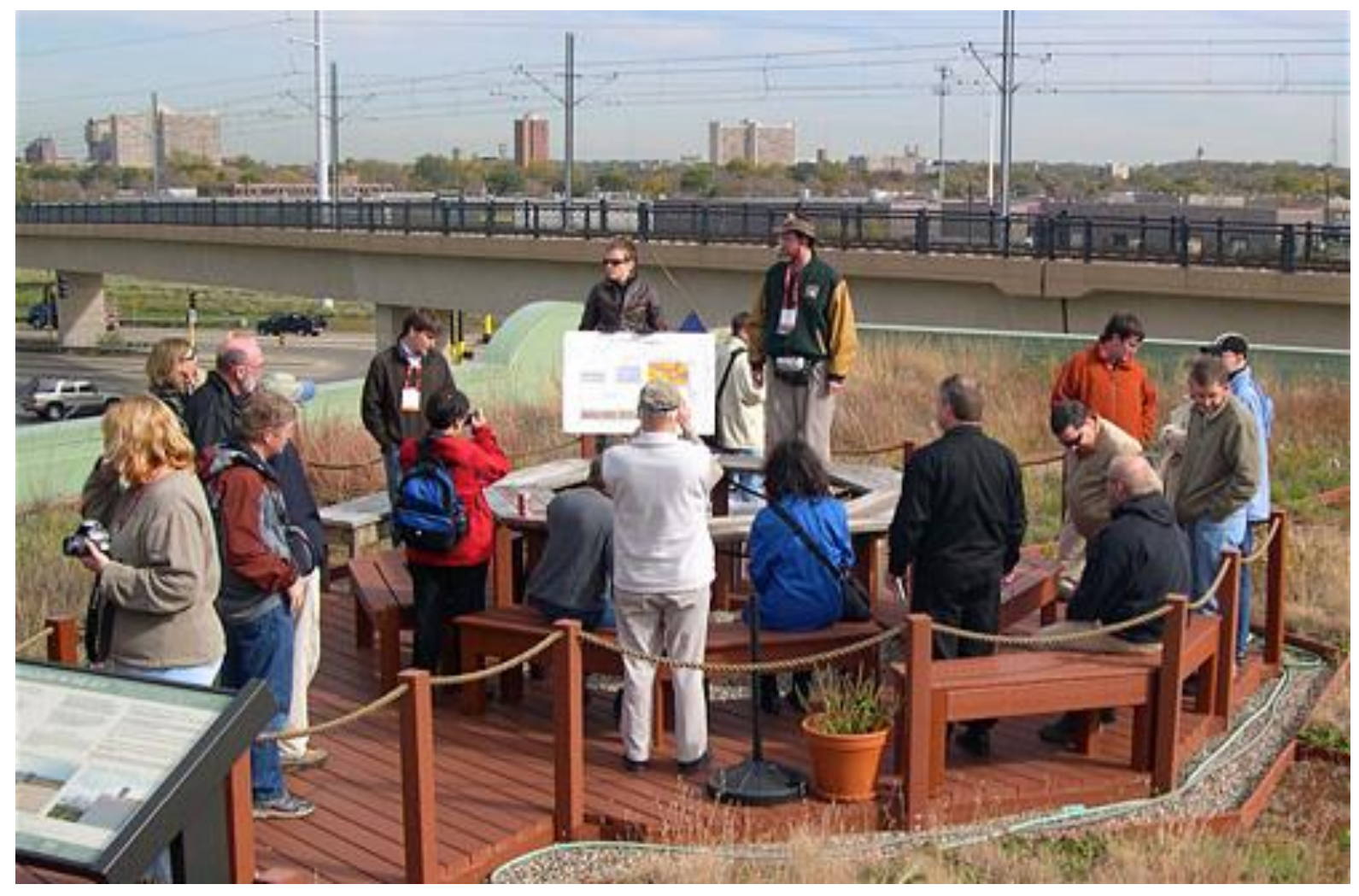

Intelligent care (Nassauer 1997) of landscapes calls on human understanding of ecological parts, relationships and systems as best we can understand them. It also requires that we be modest and humble when deciphering natural systems. Such an attitude applied to green roofs and green walls forces the designer to treat each one as an experimental creation (Sutton 2013a). Learning how these synthesized communities work as assemblages should be embedded in their design program from intent to ideation to care. When one realizes plantings on a green roof have begun to self-organize, disperse, and reproduce this knowledge should lead to a joyous reaction.

Nassauer's (1997) concept of vivid care, occurs when we "suppl[y] the visual framework of human presence" and intent with requisite knowledge about what constitutes ecological health (Figure 7). Nassauer talks about vivid care for natural and agricultural landscapes including lawn care, so the analogy with green roofs and walls may not be obvious. Green roofs and walls in one way can hardly be mistaken as natural, yet once planted and like any living or inter-connected thing, they assume a life of their own (Figure 8). They may not conform to an initial pattern and may seek their own dynamic pattern. Green roof and green wall designers already apply some specific standards of care such as stopping substrate 
erosion, removing weeds, having vigorous plants and covering sufficient area. Sustainable maintenance of green roofs and walls also fits this analogy offered by Nassauer, "Landscapes are more like children than art. They require tending more than making."

Figure 7. On the Ducks Unlimited Canada, Oak Hammock Marsh Interpretive Centre green roof, fire as a natural process vividly controls thatch build-up that threatens to smother the roof's native plant layer. (Photo Credit: Tye Gregg, Ducks Unlimited Canada.)

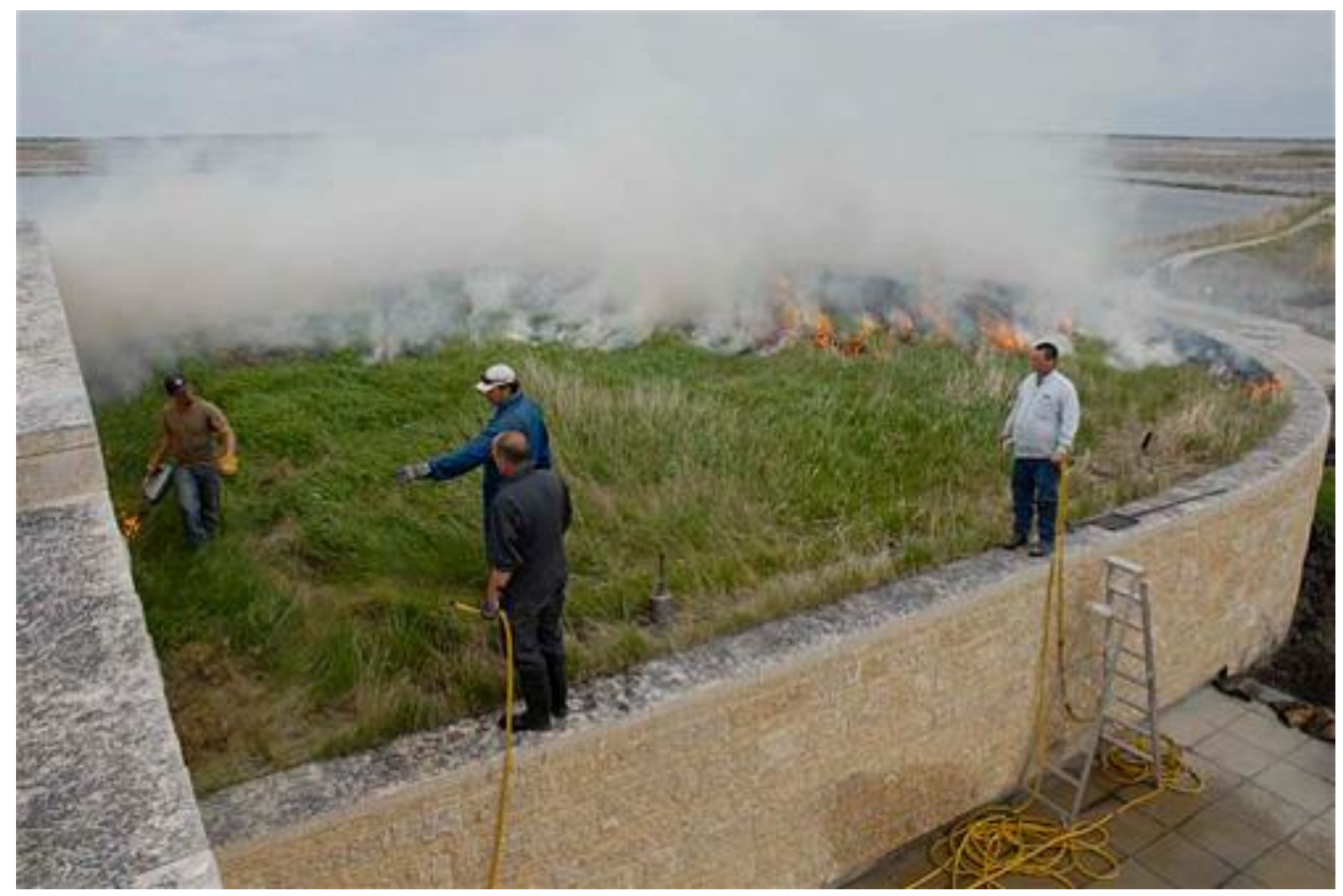


Figure 8. The initial decorative planting forms reminiscent of paisley layout on the Chicago City Hall green faded as plants reproduced in new locations and coalesced into a more random, but dynamic, and more self-organized but complex natural patterns.

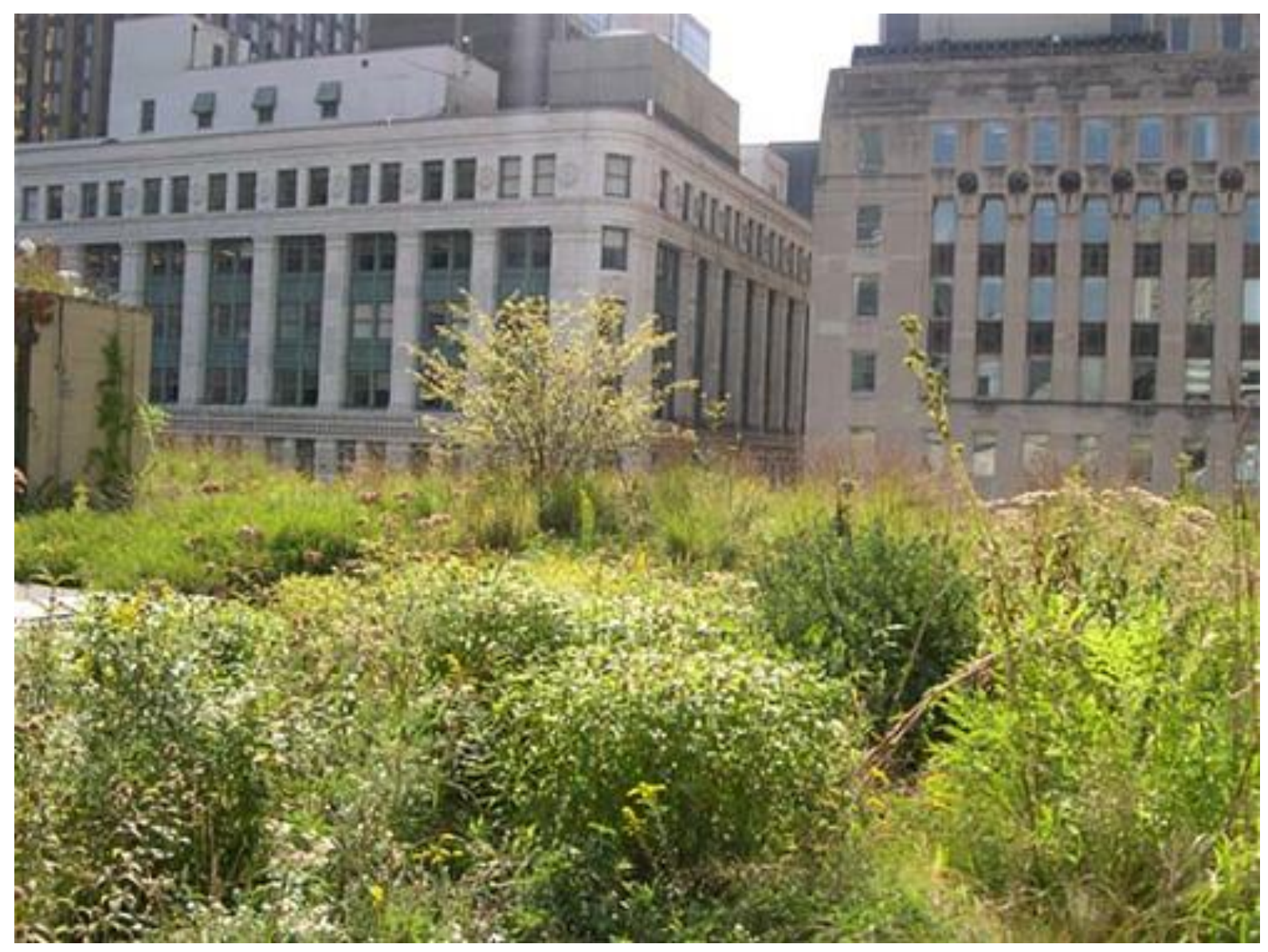

\section{ALLOW FOR CHANGE AND INCREASED BIODIVERSITY}

Concerning itself with biological variety and a hierarchy of species, ecosystems and the genes within (GRHC 2006), biodiversity fits easily within an ecological aesthetic and produces ecological beauty for green walls and roofs.

Dunnett (2010) concludes that biodiversity designed onto accessible green roofs has been guided by neither aesthetics nor studies of people's preferences. He argues that nativity of individual species, ecotypes or communities and substrates in support of green roof plantings is at best misplaced. Though acknowledging biodiversity for its own sake cannot be sustained by a public unaware of esoteric and largely scientific concepts of ecology, Dunnett fails to probe more deeply into educating people about what they see planted on green roofs and how it interacts and how gardeners seeking maximized color effects. 
As suggested above, green roofs and walls that grow, change, and become more selforganizing may on their surface look disheveled, rough and unpolished. Harries-Jones (2005) notes an, "Ecological aesthetic ... registers a relation between the parts and the whole in a manner very different from an observer pretending to be outside the setting engaged in an exercise of eco-management" (pp. 67-68). On the other hand, Nassauer (1995) points out "A neat, orderly landscape [or green roof] seldom enhances ecological function"; they "require control and domination." Horticultural green roofs and walls maintained with an ecomanagement mindset often lack biodiversity, ecological structure, and require excessive, costly outside inputs such as water, fertilizer, and labor (Sutton 2013b) (Figure 9).

Figure 9. A clipped, watered, and fertilized plant assemblage on this green roof requires constant attention to maintain the static forms and blocks of color.

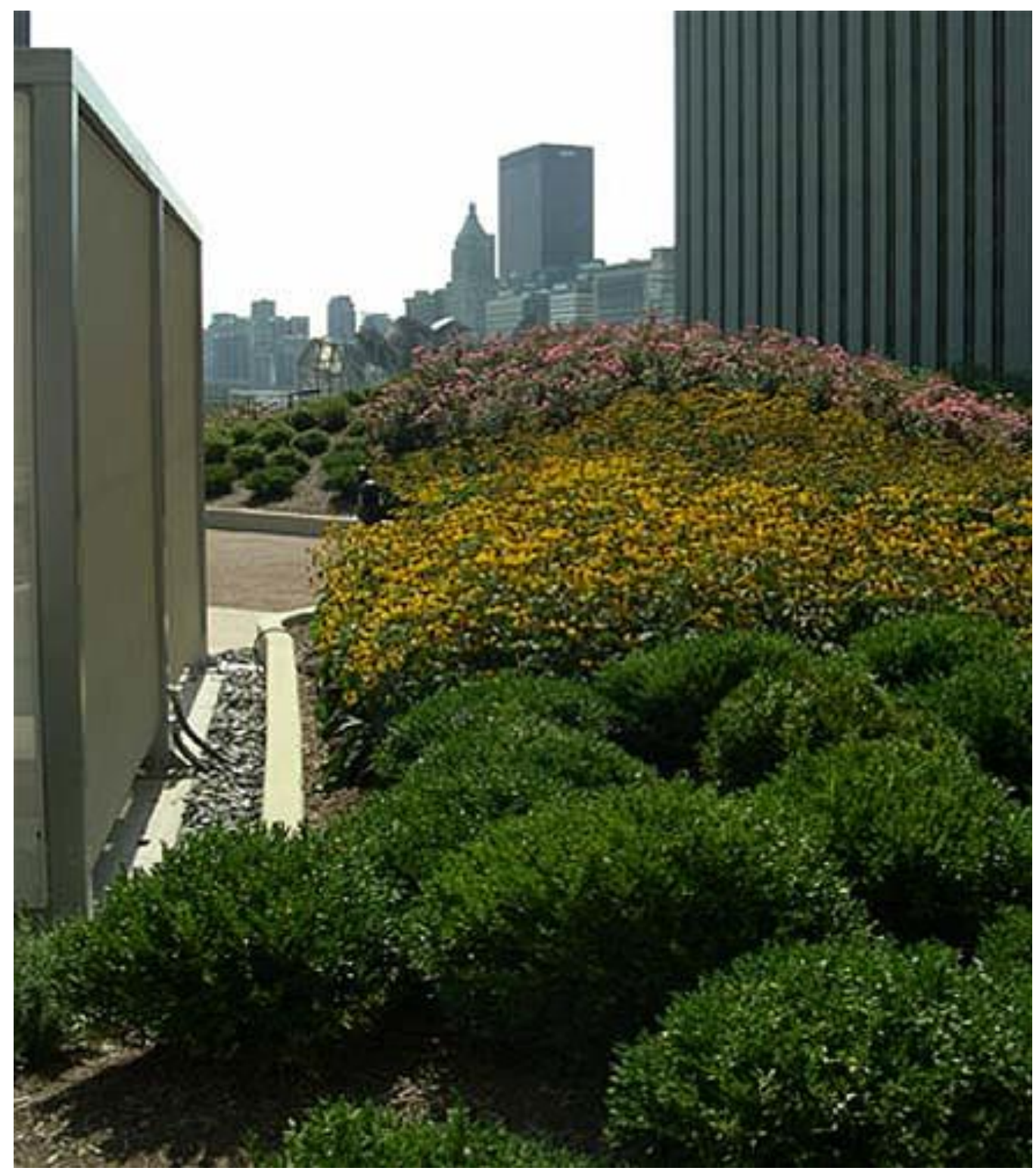




\section{DESIGN DIFFERENTLY}

Nassauer (1995) identifies the nexus of design and an ecological aesthetic as "translating ... ecological patterns into cultural language.” To do this Koh (1988) suggests revising longheld design principles by remaking unity into inclusive unity, seeing balance as dynamic balance, and adding complementarity (Pattee 1967) as a third principle. Inclusive unity brings together the participant and the environment; dynamic balance acknowledges an ecological and biological system that self-organizes and permutes over time and is always changing; complementarity revises the dualistic view from "either-or" to a qualitative, "bothand" approach thus gives a designer other ways to communicate knowing. Suzi Gablik as quoted in Harries-Jones (2005) might agree saying, "the sub-text of all art [and design] should therefore be restoring the balance, attunement to nature, together with the idea that all things are linked together in the cyclical processes of nature." (Figure 10)

Figure 10. Blocks of native grasses at the Sandhills Publishing, Inc. green roof in Lincoln, Nebraska, suggest the fuzzy natural boundaries of the nearby fields found in local agricultural landscapes rather than a hardened, precise geometry.

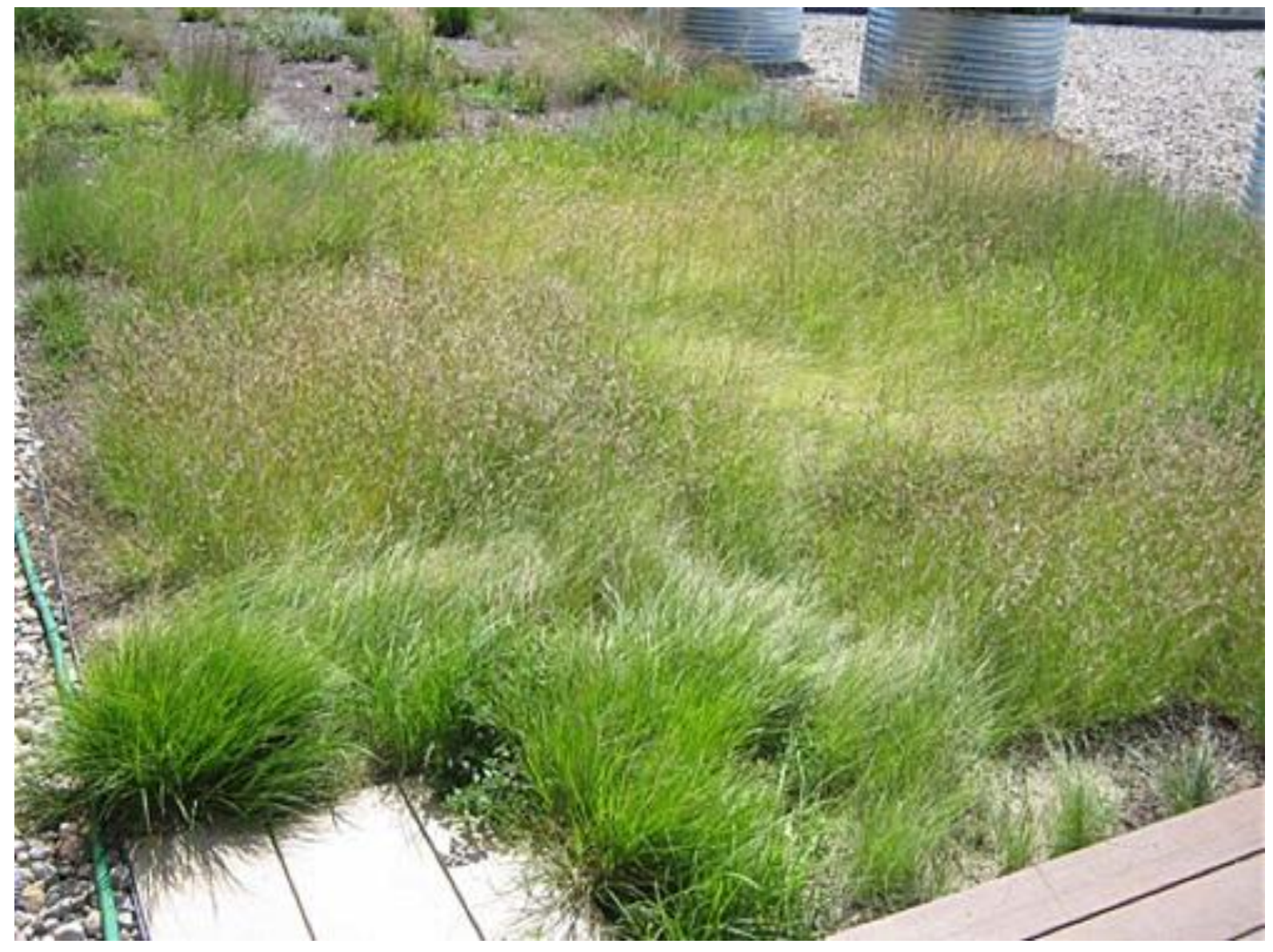




\section{Summary}

Aesthetics deals with the sensory experiences that make us value part of the material world and is non-trivial because it taps our senses and links us to the world around us. A green roof or green wall designer must certainly acknowledge all technical requirements such as site analysis, membrane selection, user access, load bearing, media composition, and plant hardiness, moisture requirements, managing sustenance etc. However, when embracing ecological beauty, he or she must have goals to conspicuously engage the user as partner and participant, to communicate the client's intentions, to educate the user about the place's unique ecology, to allow for dynamics of growth, change and self-organization and to design differently moving beyond the static, visual, and shallow in the creation. Doing so will reduce or eliminate the disvalues brought by the banal, dull, unfulfilled and trite in assembling green roof and wall plantings. 


\section{Literature Cited}

Adler, M. 1981. Six Great Ideas. New York: Macmillan.

Aquinas, T. 1274. Summa Theologica.

Bateson, G. 1979. Mind and Nature; A Necessary Unity. New York: Bantam, 1979.

Berleant, A. 1997. Living in the Landscape; Toward an Aesthetics of Environment. Lawrence, KS:U of Kansas Press.

Callicott, J. 1983. Leopold's land aesthetic. Journal of Soil and Water Conservation. July Aug.

Carlson, A. 2012 "Environmental Aesthetics", The Stanford Encyclopedia of Philosophy (Summer 2012 Edition), Edward N. Zalta (ed.), http://plato.stanford.edu/archives/sum2012/entries/environmental-aesthetics.

Dunnett, N. 2010. People and nature: Integrating aesthetics and ecology on accessible green roofs. In, Proc. 2nd Intl Conference on Landscape and Urban Horticulture. G . P. Gianquinto and F Orsini (eds.). ISHA Acta Horticulturae 881.

Gobster, P. 1999. An ecological aesthetic for forest landscape management. Landscape Journal 18 (1) 54-64.

GRHC. 2006. Biodiversity Workshop Participant's Manual. Toronto: Green Roofs for Healthy Cities.

Harries-Jones, P. 2005. Understanding Ecological Aesthetics. Cybernetics and Human Knowing, 12 (1-2) 61-74.

Kant, Immanuel, 1790. Critique of Judgment, Translated by J. H. Bernard, New York: Hafner Publishing, 1951. (Original publication date 1892)

Koh, J. 1988. Ecological Aesthetics. Journal of Landscape Architecture. 7 (2) 177-191.

Lee, H., and H. Koshimitz. 2006. Research on the Scenic Meaning of Rooftop Greening with Semantic Differential Measure and Join-count Statistics in, Proceedings 4th Annual Greening Rooftops for Sustainable Communities Conference. Boston, MA. Cardinal Group, Toronto.

Leopold, A. 1966. A Sand County Almanac. New York:Balantine Books.

Nassauer, J. 1995. Messy Ecosystems, Orderly Frames. Landscape Journal. 14(2) 161-170. 
Nassauer, J. 1997. Cultural sustainability: Aligning aesthetics and ecology. In Placing Nature: Culture and Landscape Ecology, J. Nassauer (ed) pp. 67-83. Washington, DC:Island Press.

Pattee, H. 1979. The complementarity principle in biological and social structure. Journal of Biological and Social Structures. 1:191-200.

Sutton. R. K. 2013a. Seeding green roofs with native grasses. Journal of Living Architecture. 1 (1) 23p. http://livingarchitecturemonitor.com/index.php/journal/research

Sutton. R. K. 2013b Rethinking extensive green roofs to lessen emphasis on above-ground biomass. Journal of Living Architecture. 1 (1) 3p. http://livingarchitecturemonitor.com/index.php/journal/research

Thayer, R. 1989. The experience of sustainable landscapes. Landscape Journal. 8(2) 101-110.

Ulrich, R. 1984. View through window may influence recovery from surgery. Science April 271984 224: p 420(2)

\section{Acknowledgements}

We wish to thank Dr. Paul Gobster for input into this article and to thank the Vancouver Convention Centre and Ducks Unlimited Canada for allowing reprint of their photographs. This article was given as a paper at the Atmospheres 5: Ecology and Design conference at the University of Manitoba February 7-9, 2013. Research was funded in part by a UN-Lincoln, Department of Agronomy and Horticulture Fleming Horticulture Research Grant. 